\title{
MALAY TRADITIONAL GAMES ARE NEVER A LOSS: AN EMOTIONAL REFLECTION OF MALAYSIANS AND IMMIGRANTS IN MALAYSIA
}

\author{
Nasir YUSOFF ${ }^{*}$ \\ Universiti Sains Malaysia, Department of Neurosciences, School of Medical Sciences, \\ Health Campus, 16150 Kubang Kerian, Kota Bharu, Kelantan, Malaysia, e-mail:nasirff@usm.my \\ Hue San KUAY \\ Universiti Sains Malaysia, Department of Psychiatry, School of Medical Sciences, \\ Health Campus, 16150 Kubang Kerian, Kota Bharu, Kelantan, Malaysia, email: huesankuay@usm.my \\ Rabeta MOHD SALLEH \\ Universiti Sains Malaysia, School of Industrial Technology, 11800 Minden, Pulau Pinang, Malaysia, email: rabeta@usm.my
}

Rohani ISMAIL

Universiti Sains Malaysia, Interdisciplinary Health Science Unit, School of Health Sciences, Health Campus, 16150 Kubang Kerian, Kota Bharu, Kelantan, Malaysia, e-mail: rohanis@usm.my

Roslee AHMAD

Universiti Sains Islam Malaysia, Faculty of Leadership and Management, 71800 Nilai, Negeri Sembilan, Malaysia, e-mail: rosmad@gmail.com

\section{Audrey ANTOINE}

Universiti Sains Malaysia, Department of Neurosciences, School of Medical Sciences, Health Campus, 16150 Kubang Kerian, Kota Bharu, Kelantan, Malaysia, e-mail: audreyantoine95@hotmail.com

Citation: Yusoff, N., Kuay, H.S., Mohd Salleh, R., Ismail, R., Ahmad, R., \& Antoine, A. (2020). MALAY TRADITIONAL GAMES ARE NEVER A LOSS: AN EMOTIONAL REFLECTION OF MALAYSIANS AND IMMIGRANTS IN MALAYSIA. GeoJournal of Tourism and Geosites, 31(3), 1004-1009. https://doi.org/10.30892/gtg.31311-534

\begin{abstract}
Introduction-Aims: In the modern days, traditional games have been perceived less preferred than universal games. This study examines the emotional reflection of Malaysians and Immigrants in Malaysia towards Malay traditional games and universal games. Malays (ethnic majority), Malaysian minorities (Chinese and Indian) and immigrants responded to the displayed images of Malay traditional games and universal games using a 9-point rating scale for valence domain of Self-Assessment Manikin. The emotional pleasantness towards Malay traditional games are higher in immigrants than Malaysians. There are emotional similarities between Malays and Malaysian minorities. Socio-cultural factors should be examined in future research to further understand this cultural situation.
\end{abstract}

Key words: Cultural heritage, emotion, valence, immigrant, ethnic minority

$* * * * *$

\section{INTRODUCTION}

\section{Malays as an Ethnic Majority and Traditional Games}

Malaysia is a multi-ethnic and multicultural society. The Malay ethnicity comprises more than $50 \%$ of the Malaysian population (Department of Statistics Malaysia, 2020). Besides being the dominant ethnic majority in Malaysia, the Malays are known for their richness in tradition. The characteristic of Malays can be usually determined from their language (i.e. Malay language), adhere to Islam religion and practice Malay tradition. A large proportion of Malays can be found dispersed in Malaysia (formerly known as Malay Land) and Indonesia. It is believed that the Malay traditional heritage expanded during the era of the Malacca Sultanate by the Malay traders who at that time sailed across the Southeast Asia region (Hooker, 2003; Wolters, 1999). Currently, the Malay heritage especially in the Malaysian population is still strong despite crossing many generations. A strong practice of the Malay tradition can be seen through many aspects of Malay life as well as the lives of other ethnic minorities especially in games, food, and clothing.

There are several traditional games in the Malay community that attract both the young and old generation in Malaysia to engage in, such as wau bulan, sepak raga, batu seremban, gasing, silat, congkak, gasing, and wayang kulit. Some of these traditional games are of gender dominance. For example - sepak raga, wau bulan and gasing are among the traditional games that are usually played by males. Meanwhile congkak is frequently played by females. Some games are popular among both sexes. The Malay traditional games can also be characterized through the number of players involved. The wau bulan, gasing, wayang kulit, silat and traditional dance as well as music can be played individually. These games are different from some other games (i.e. sepak raga, tarik upih, congkak) that need more than one player to take part. In terms of objects that are being used in the games, most of the objects are made from wood and bamboo. Some objects are made from animal skin such as cow skin. The similarities and differences between these games are highlighted in Table 1 .

It is believed that the culture of Arabians and Indians have influenced the development of traditional games in the Malay community during the era of the Malacca Sultanate dated back in the $17^{\text {th }}$ century. Back then, Malacca was located in a strategic area for international trading that attracted traders all around the world. This situation encouraged the growing of the social-cultural development of the Malay community in Malay Land (Malaysia). Over the generation and evolution, these traditional games became more advanced in their

\footnotetext{
${ }^{*}$ Corresponding author
} 
decorations and materials. For example, the rubber seeds used in congkak, these days have been replaced with marbles. Similarly, the decoration of the wau bulan has become more creative and attractive. Due to its attractiveness and uniqueness of the shape, the wau bulan has been adopted as a symbol for the national airline company. In addition, a number of Malay traditional games (i.e., sepak raga and silat) have been recognized at an international level such as South East Asia (SEA) Games (Department of National Heritage Malaysia, 2020).

\section{The Ethnic Minorities in Malaysia - Chinese and Indian}

The Chinese and Indian are the largest ethnic minorities in Malaysia. It has been estimated about 25\% of Chinese and 7\% of Indians are living in Malaysia, followed by other minority groups (i.e., Sikh, Thai, Eurasian) (Department of Statistics Malaysia, 2020). From Malaysian history, it is shown that the existence of both Chinese and Indian population in Malaysia is due to migration that happened in the $17^{\text {th }}$ century. The reason for their migration was mainly due to the economic situation at that time where they were hired as laborers under the British colonization (Othman, 2002; Punitha and Kumaran, 2014; Shafie and Zainudin, 2000). Historical documentation also stated that both the Chinese and Indian population in Malaysia (or Malay Land) was because of matrimonial factor between the Chinese and Indian from mainland and the local Chinese and Indian (Shafie and Zainudin, 2000). This scenario is linked to the era of the Malacca Sultanate at that time due to Malacca (one of the states in Peninsular Malaysia, located in Malacca Strait) being popular as a strategic location for a trading centre that encourages merchants from all over the world (especially Chinese from mainland China and Indians from India) to come over for trading activities and thus, providing a pathway for the growth of their population. Hence, it can be said that the growth of the socioeconomic status in Malay Land at that time was a source of encouragement for both ethnicities (Chinese and Indian) to adapt and merge their cultural elements and the cultural elements of the Malay people. The socio-economic factor is the reason of both Chinese and Indian ethnicities to be always present, continuous and harmonious across generations in Tanah Melayu (Othman, 2002; Punitha and Kumaran, 2014; Shafie and Zainudin, 2000). It is believed that the merging of culture between majority and minority ethnicities had taken place throughout generations, and even after hundreds of years. The effects of culture blending between Malay and non-Malay tradition can be seen in various aspects such as clothing, food, games and so on (Zainal Abidin et al., 2016; Ubaithulla, 2001).

Table 1. Description of Malay traditional games (Department of National Art and Culture Malaysia, 2020)

\begin{tabular}{|c|c|c|c|c|}
\hline Name & Gender & Player & Object & Brief Method \\
\hline Wau bulan & Male and female & Individual & Kite-shaped, made of bamboo & The wau bulan is flown in the air \\
\hline Sepak raga & Male & Group & Ball-shaped - made of bamboo & $\begin{array}{l}\text { The bamboo ball is kicked around by the players } \\
\text { in a circle. The goal of the game is to ensure the } \\
\text { bamboo ball does not fall onto the ground. }\end{array}$ \\
\hline Gasing & Male & Individual & Plate-shaped - made of wood & $\begin{array}{l}\text { Gasing is spun by a string and is left to spin on } \\
\text { the ground. }\end{array}$ \\
\hline Wayang kulit & Male & Individual & $\begin{array}{l}\text { Puppet or character - made of animal } \\
\text { skin/paper and bamboo }\end{array}$ & $\begin{array}{l}\text { Puppet is moved behind a canvas acting out a } \\
\text { character. The voice is presented by people } \\
\text { behind the scene. }\end{array}$ \\
\hline Tarik upih & $\begin{array}{l}\text { Male and } \\
\text { female }\end{array}$ & $\begin{array}{l}\text { Group } \\
\text { (Children) }\end{array}$ & Pinang tree leave. & $\begin{array}{l}\text { Several passengers (players) sit on the leaf and } \\
\text { one player will pull the leaf. }\end{array}$ \\
\hline Congkak & Female & $\begin{array}{l}\text { Group } \\
\text { (Two } \\
\text { players) }\end{array}$ & $\begin{array}{l}\text { A container with } 16 \text { holes that is created with } \\
\text { high quality wood and played with rubber seeds. }\end{array}$ & $\begin{array}{l}\text { This game evaluates the speed of its players } \\
\text { depending on how fast the player can put the } \\
\text { rubber seeds into the holes of the congkak container. }\end{array}$ \\
\hline Silat & Male & Individual & No object is used & Dealing with physical technique. \\
\hline $\begin{array}{l}\text { Traditional dance } \\
\text { and music: } \\
\text { Kompang, } \\
\text { Gambus, Rebana } \\
\text { and Kuda Kepang }\end{array}$ & $\begin{array}{l}\text { Male and } \\
\text { female }\end{array}$ & Individual & $\begin{array}{l}\text { Objects are used to produce unique sound. } \\
\text { Kompang and Rebana are the bowl-shaped object, } \\
\text { made of animal skin and wood. Gambus is like the } \\
\text { modern guitar, made of wood. Kuda kepang is } \\
\text { a horse-shaped object, made of wood. }\end{array}$ & $\begin{array}{l}\text { Kompang, gabus and rebana are hit like drums to } \\
\text { produce the melody of traditional music or sound. } \\
\text { Meanwhile in kuda kepang, player riding a horse- } \\
\text { shaped object following the traditional melody. }\end{array}$ \\
\hline
\end{tabular}

\section{The Immigrants in Malaysia}

Migration is a social issue that has a great impact on socio-cultural and humanity (Abdul Wahab and Khairi, 2019; Bali et al., 2019; Sahak et al., 2020). Immigrants are known as a group of people who migrate and live in certain country (outside of their origin country) for a certain duration of time for various reasons. Immigrants in Malaysia are a group of non-Malaysians that are living in Malaysia for the purpose of studying, vacation, working and family matters. They are a group that highly predispose to the culture of other people in the country of residence. According to Hall et al. (2004), travellers (or could be referred to the immigrants as well) have different motives in their travelling purposes. For example, food could be targeted as a primary or secondary motive depending on their preferences.

The experience of immigrants towards other people's culture has been described many decades ago by sociologist. From the viewpoint of a sociologist, the mixing with other cultures is a socio-cultural phenomenon that is known as acculturation. After a long period, the mixing of culture is to potentially yield to the new form of culture with a new identity (Ben-Shalom and Horenczyk, 2003; Cote, 2006). The process of change in beliefs and traditional practices happens when one culture meets the other culture which results in the merging of the original culture and the newly encountered culture is another description of acculturation (Berry, 2005; Sam and Berry, 2010). Acculturation has brought a lot of influence on immigrants. Strong influence of acculturation can be observed in many aspects of their life, not only in food preparation and clothing but also in their activities during free time such as playing Malay traditional games (Zhang et al., 2019).

\section{Research Strengths and Highlights}

This study adopts the visualization approach to explore the cultural-emotion dimension with regards to the traditional games of Malay ethnicity. Throughout this approach, two important aspects are highlighted as below:

(1) The Valence: we measured the element of 'valence' - an emotional domain that interprets one aspect of subjective feeling that underlies the pleasure-displeasure continuum (Russell, 1991). The Circumplex Model of Affect points out that valence is one of the basic structures in the building block of emotion (Barrett 2006a; Barret 2006b) and has been integrated in many psychological models and frameworks (Rolls, 1999; Russell, 2003; Styliadis et al., 2018). In addition, valence is a fundamental element that reacts to positive and negative traits as triggered by object or non-object stimuli.

(2) The Theory of Gestalt: this theory is referred to justify that perception towards image could be a significant predictor to determine emotional tendency. This underlying fact has been notified by researchers in the field of psychology to understand perception (Feldman, 
2001; Kimchi, 2000; Peterson and Kimchi, 2013; Wagemans et al., 2012). In reality, both human and animal goes through the process of visualization in their everyday life by synthesizing information from the environment for survival. In fact, visualization involves not only our eyes, but our biological and psychological wellbeing as well. Thus, through the Gestalt Theory that suggests eight principles of visualization that effects image perception, we picked up two principles that are most relevant to our study. These are the law of similarity and the law of past experience. Law of similarity suggests that we tend to assemble images with similar characteristics in a group that is different from images with dissimilar characteristics. Following this law, we postulate that the traditional games images will be responded differently from the non-traditional games images. Meanwhile in the second law, the exposure with the previous experience would influence the psychological and emotional dimension in response towards the images (i.e., images of the traditional Malay games). Following this argument, we hypothesize that, Malays would indicate higher pleasantness towards the traditional Malay games followed by Malaysian minority (i.e., Chinese and Indian) and immigrant. This hypothesis has been put forward due to the historical fact that Malay ethnicity is a majority ethnic group that is recognized as a pioneer of Malay Land (Malaysia) prior to the migration of the ethnic minorities.

The above two hypotheses drive us to further construct the hypothesis, which is the main hypothesis of this current study. The law of experience from the Theory of Gestalt, for example, indicates significant implication in the subjective experience of valence (Posner et al., 2005; Russell, 2003). It is suggested that there would be a significant interaction between emotional response towards traditional/nontraditional image (with regards to Malay traditional games and universal games) and the variety of socio-ethnic groups who are living in Malaysia (i.e. Malay-the ethnic majority, ethnic minority and immigrants). It is to note that we are using the operational definition of tourist in which the meaning of tourist is expanded by including participants (tourists) from various purposes of travelling (studying, vacation, working and so on) with no time limit of being in Malaysia.

\section{MATERIALS AND METHODS}

\section{Participants and Location of Study}

Undergraduates and postgraduates from a local university in the east coast of Peninsular Malaysia were invited to participate in this study. This local university is located in Kelantan - one of the states in Malaysia that is rich with cultural tradition of the Malay ethnicity. Through convenience sampling, three categories of participants agreed to take part in this study - (1) ethnic majority (Malaysian Malays., $\mathrm{n}=116$ ), (2) ethnic minority (Malaysian Chinese and Indian, $\mathrm{n}=100$ ) and (3) immigrants (non-Malaysian, $\mathrm{n}=119$ ). Participants are in the group of young adults with ages ranged from 17 to 40 years old with a mean age of $24.2(S D=4.8)$. More than half of the participants were female $(n=222,66 \%)$. All immigrants originated from countries that are totally different from Malaysia with regards to the tangible and intangible culture - South Asia (42\%), West Asia (30\%) and Africa (28\%). Participants who did not match the inclusion criteria of the study were excluded. Excluded participants are those with uncorrected vision, a history of affective disorder, and those born in a mixmarriage family (Malay and Chinese, Malay and another ethnicity, Chinese and another ethnicity). Other than that, immigrants who had neither Malaysian spouses nor Malaysian parent (either father or mother or both) were also excluded from the study in order to avoid any emotional biasness in response to culture images.

\section{Procedure}

Research procedure was implemented based on the protocol and ethics approval given by Institutional Review Board (IRB). Consent was only obtained from the participants after they had fully understood the objective and the procedure of the study and agreed to participate. The welfare of the participants was considered by allowing them to withdraw from the study at any point of time as well as distribution of token to compensate their time and expenses to the study location.

Data collection was done cross sectionally and it was implemented in the university's lecture hall. Unlike other approaches in games research (Carr, 2019; Klevjer, 2019), this current study applied the visualization approach in which participants were asked to respond to a series of culture (i.e. Malay traditional games) and non-culture images (i.e. universal games) that were presented to them. They were required to view the presented images that were projected on the screen and estimate their emotional condition by rating a single-item scale of SelfAssessment Manikin (SAM) (Bradley and Lang, 1994) (Figure 1). The SAM is a standardized non-verbal pictorial assessment that was developed to appraise three important emotional domains which are valence, arousal, and dominance (Bradley and Lang, 1994). It is a wellknown psychological assessment that has been used broadly as a cost and time-effective measure of emotion (Bynion and Feldner, 2017; Geethanjali et al., 2017). By using SAM, this study focused on the domain of valence or a state of pleasure in emotion dimension that refers to the intrinsic attractiveness or aversiveness when triggered by an event, object, or situation which can be positive or negative. Since this study used the images of culture and non-culture objects and all images were considered positive, thus, it has to be noted that the emotional valence is evoked or triggered by the object with positive element. Participants rated the SAM valence scale that ranges from high pleasantness/highly happy (score of 9) to minimal pleasantness/highly unhappy (score of 1).

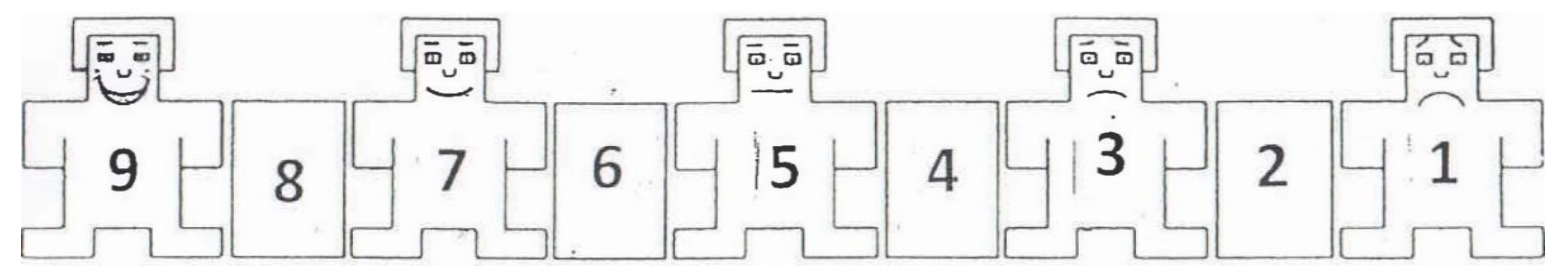

Figure 1. Emotional continuum of Self-assessment Manikin (SAM) for valence - 1 (unpleasantness/unhappy) to 9 (pleasantness/happy)

About 13 cultural images and 13 non-cultural images were presented randomly to evoke the participants' emotion. The cultural images are the set of images that displayed the traditional games in Malay community such as wau bulan, silat, gasing and others. Some of the images are shown in Figure 2. Meanwhile the non-cultural images are the set of images that displayed the well-known universal games that do not relate to any culture such as playing guitar, basketball and others. To ensure that all culture images have an established content validity, three evaluators were invited to give their judgements. An academician and science officer that have wide experience in the area of Malaysian culture especially Malay culture, were asked to view and rate the displayed images based on a 4-point scale (i.e., $1=$ not relevant, $2=$ somewhat relevant, $3=$ quite relevant, and $4=$ highly relevant) (Davis, 1992) in order to determine the relevancy of the cultural images as Malay traditional games. The Content Validity Index (CVI) calculation was based on the score of 3 and 4 only. The sign X will be given if the score is 3 or 4 from each evaluator. The calculation (Davis, 1992) is depicted as below: Number of X / Number of Evaluators 


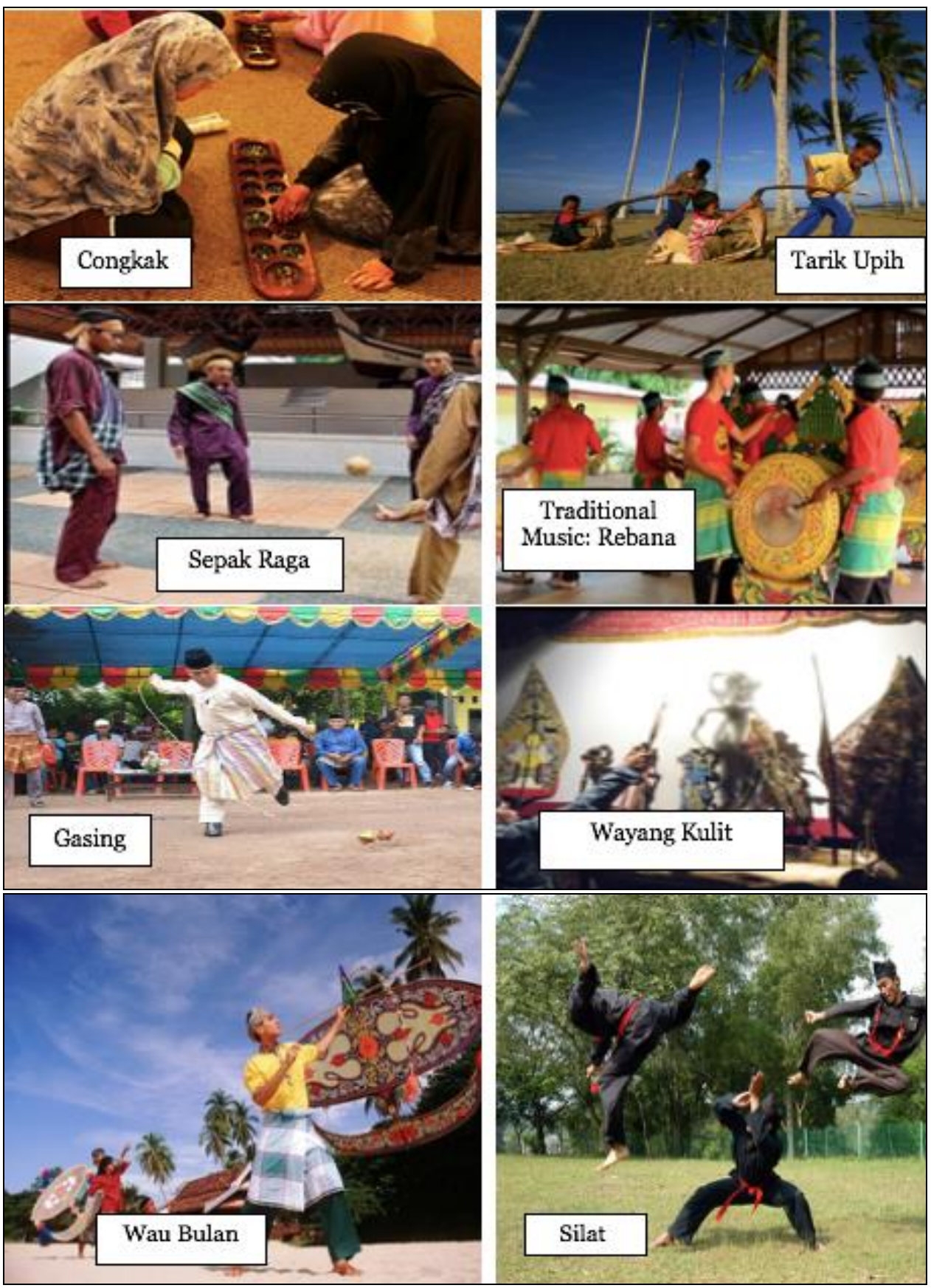

Figure 2. Malay traditional games (All images are confirmed to be free from copyright policy)

The above process was applied for the non-culture images as well in which the evaluators have to determine the relevancy of images as universal games. Since the value of the index for items (I-CVI) was one for all images, the content validity was assumed acceptable (Davis, 1992). Other than the above, all these cultural images have been given acknowledgment by the Department of National Heritage Malaysia (2018) as a tangible cultural heritage of Malaysia.

\section{Statistical Analysis}

Data was analysed with the Statistical Package for the Social Sciences (SPSS) Version 23. The analysis of variance (ANOVA) for a two-way mixed design was carried out to delve the interaction effect between the socio-ethnicity groups (three levels of between-subjects effect: 1 . Malay - the ethnic majority, 2. Malaysian minority and 3. immigrant) and the emotional pleasantness (valence domain) when triggered by different types of game images (two levels of the within-subjects effect: 1. Malay traditional games and 2. Universal non-culture games). Pairwise comparison was also reported to determine the specific pattern of interaction that existed between each group of socio-ethnicity. The degree of freedom of the F ratio was corrected (if any) according to the Huynh-Feldt method along with the assumption of sphericity.

\section{RESULTS AND DISCUSSION}

The internal consistencies of both types of images were acceptable - Cronbach's alpha was 0.85 in culture images (Malay traditional games) and 0.83 in non-culture images (Universal games). From the analysis of variance of two-way mixed design, the significant interaction effect between socio-ethnicity groups (Malays, Malaysian minority and immigrant) and the different types of images (Malay traditional games and universal games) was observed $[\mathrm{F}(2,332)=4.7, \mathrm{p}<0.01]$ (Table 2). 
Nasir YUSOFF, Hue San KUAY, Rabeta MOHD SALLEH, Rohani ISMAIL, Roslee AHMAD, Audrey ANTOINE

Table 2. The emotional effect from the interaction between socio-ethnicity groups and different types of images

\begin{tabular}{|c|c|c|c|c|c|c|}
\hline & \multicolumn{3}{|c|}{ Mean (Standard Deviation) } & \multicolumn{3}{|c|}{ Interaction Effect } \\
\hline & Malays & Malaysian minority & Immigrant & df & $\mathrm{F}$ & p-value \\
\hline Malay traditional Games & $5.24 \pm 1.27$ & $5.59 \pm 1.13$ & $6.15 \pm 1.18$ & \multirow[b]{2}{*}{2} & \multirow[b]{2}{*}{4.70} & \multirow[b]{2}{*}{$0.01 *$} \\
\hline Universal Games & $5.40 \pm 1.30$ & $5.71 \pm 0.91$ & $5.99 \pm 1.15$ & & & \\
\hline
\end{tabular}

*significant level: $p<0.001 ; d f=$ degree of freedom; $\mathrm{F}=$ Freedom

In the pairwise comparison, the immigrant group indicated significantly higher emotional pleasantness in viewing the Malay traditional games than universal games $[t(118)=2.72, p=0.008]$. However, the difference in emotional response between Malay traditional game images and universal images was not seen in Malay group $[t(115)=1.70, n s]$ and Malaysian minority $[t(99)=1.31, n s]$.

Throughout this study, in general, we found significant interaction effect of emotional pleasantness (i.e. valence) in response towards the images (Malay traditional games versus universal games) across the various groups of socio-ethnicity (i.e. Malay, Malaysian minority and immigrant). In specific, we found that emotional pleasantness (i.e. valence) among immigrants is significantly higher in response towards Malay traditional games images as compared to universal games images. However, this situation was not seen in other socio-ethnicity groups (i.e. Malay and Malaysian minority). Even though we found the interaction effect between socio-ethnicity groups and type of images on emotional response, however, our specific finding in which the emotional response towards the cultural games images is higher in immigrants as compared to Malaysians (i.e. Malay and Malaysian minority) is somewhat controversial. We tend to argue this situation is due to the effect of valence in visualization process. This emotional pattern is possible when we referred our findings to the previous electrophysiological study. For example, it has been noted that positive images with high valence indicated high level of amplitude in several electroencephalography components such as P300 and P200, among participants with extraversion trait (Yuan et al., 2012). Perhaps, the extraversion trait is greater among immigrants in our study that made them expressed higher emotional valence. Another possibility is that, the high ratings of emotional pleasantness among immigrants is perhaps linked to the trait of 'openness to experience' as this trait indicates connection with extraversion (Canache et al., 2013). Openness to experience is described as one of the personality traits that is characterized by one's receptivity towards new ideas and new experiences (McCrae and John, 1992). People with this trait usually like to seek out various experiences and tend to have high levels of curiosity. It is mentioned that people with high level of openness enjoy harmonization within cultural diversity and look at cultural diversity as a beneficial socio-environment (Sparkman et al., 2019).

However, we did not measure these personality variables as they are not in our scope of study. Another important finding in this study is that Malay ethnic group indicated similarity (insignificant difference) in their emotional pleasantness towards Malay traditional games images and universal games images. Likewise, the Malaysian minority (i.e. Chinese and Indian) also indicated similarity (insignificant difference) in their emotional pleasantness towards Malay traditional games images and universal games images. During crosscheck, these two socio-ethnic groups (i.e. Malay and Malaysian minority) did not show any significant difference. The above-mentioned findings have to be interpreted cautiously. We justified these findings from two points of view - (1) Modernization and urbanization, and (2) Acculturation.

The similarity in emotional response towards Malay traditional games images and universal games images that were seen among Malay and Malaysian minority is not in line with our hypothesis. However, this situation could be expected mainly due to the influence of modernization in todays' life. At an angle, it points to the fact that the Malay cultural heritage has an equal position with modernization. In other words, Malay heritage is able to compete against the challenges of modernization. Modernization is the process of astronomical social changes that once it begins, it goes through all aspects of life from economic activities to social life and to political institutions, in a selfencouraging process. It brings the idea of evolution of change in awareness and innovation, in relation to the idea of the progression of human society (Inglehart, 2007). The theory of modernization interprets that cultural trait is much affected along the process of modernization and urbanization (Gavrov and Klyukanov, 2015; Kendall, 2007). It also claims that the development of traditional society can be seen from the modern practices. We applied our findings to the theory of modernization as this theory is able to explain the social progress and development of societies and its interconnection with psychosocial change (Mattison and Sear, 2016).

Modernization comes along with urbanization; therefore, urbanization is identified as another reason that supports our findings. Urbanization which refers to the increase in the number of cities and urban population should be understood comprehensively that factors such as socio-economic and psychological changes constitute the demographic movement. Another point is that, urbanization is a process that drives the development of geographic area as a result of industrialization and economic progress (Turan and Besirl, 2008). The issue of urbanization should be paid attention to beyond the physical and environment matter in which the neurobiology effect was pinpointed along with other social parameter such as social capital (Lambert et al., 2015; Pridmore et al., 2007). Malaysia is a country that obtained its independence from colonization in 1957. Currently, after 60 years of independence, Malaysia stands as one of the developing countries in Asia with rapid growth in social and economic development. Globalization has given much impact in the process of modernization and urbanization in Malaysia. In fact, the issue of urbanization bringing impact especially on psychological well-being has been noticed since many years ago, as well as debates on urbanization from the lens of different cultures (Caracci and Mezzich, 2001).

With regards to similarity in emotional pleasantness between Malay and the ethnic minorities in Malaysia, that can be linked with acculturation. It has been mentioned in the introduction section that the minority group in Malaysia (i.e., Chinese and Indian) has gone through a long process of acculturation - a process that deals with the adapting and mixing of one culture into another culture (Berry, 2005). In the case of ethnic minorities in Malaysia, it has been documented in Malaysian history that these ethnic groups had migrated to Malay Land (Malaysia) thousands of years ago. Since then, the majority culture (i.e., Malay culture) is adopted and practiced in many aspects of their life.

\section{CONCLUSION}

Different group of socio-ethnicity indicates different emotional reflection towards traditional and non-traditional games. The traditional Malay games are found to be on par with universal games. In fact, Malay traditional games were given more attention by the immigrants. Modernization, urbanization, acculturation and personality are among the possible factors that may explain the interaction of socio-ethnicity groups and the emotional reflection towards Malay traditional and non-traditional games that are needed to be explored in future.

\section{Acknowledgment}

This work was supported by the Ministry of Education, Malaysia under Fundamental Research Grant Scheme (203.PPSP.6171204).

\section{REFERENCES}

Ab. Wahab, A. \& Khairi, A. (2019). Moving onward: Transnationalism and factors influencing Rohingyas' migration from Bangladesh to Malaysia. Journal of Nusantara Studies, 4(1), 49-68. http://dx.doi.org/10.24200/jonus.vol4iss1pp49-68

Bali, S., Liu, M.C., \& Lin, H.H. (2019). Pursuing higher education careers and the process of migration among Indonesian female migrant workers in Taiwan. Journal of Nusantara Studies, 4(2), 302-317. https://doi.org/10.24200/jonus.vol4iss2pp302-317 
Barrett, L.F. (2006a). Are emotions natural kinds? Perspectives on Psychological Science, 1 (1), 28-58, https://doi.org/10.1111/j.1745-6916.2006.00003.x

Barrett, L.F. (2006b). Solving the emotion paradox: categorization and the experience of emotion. Personality and Social Psychology Review, 10 (1), 20-46. https://doi.org/10.1207/s15327957pspr1001_2

Ben-Shalom, U., \& Horenczyk, G. (2003). Acculturation Orientations: A Facet Theory Perspective on the Bidimensional Model. Journal of Cross-Cultural Psychology, 34 (2), 176-188. https://doi.org/10.1177/0022022102250249

Berry, J.W. (2005). Acculturation: Living successfully in two cultures. International Journal of Intercultural Relations, 29(6), 697-712. https://doi.org/10.1016/j.ijintrel.2005.07.013

Bradley, M.M., \& Lang, P.J. (1994). Measuring emotion: The Self-assessment manikin and the semantic differential. Journal of Behavior Therapy and Experimental Psychiatry, 25(1), 49-59. https://doi.org/10.1016/0005-7916(94)90063-9

Bynion, T.M., \& Feldner, M.T. (2017). Self-assessment manikin. In Zeigler-Hill \& T. K. Shackelford. Encyclopedia of personality and individual differences. Switzerland: Springer International Publishing.

Canache, D., Hayes, M., Mondak, J.J., \& Wals, S. (2013). Openness, extraversion and the intention to emigrate. Journal of Research in Personality, 47 (4), 351-355. https://doi.org/10.1016/j.jrp.2013.02.008

Caracci, G., \& Mezzich, J.E. (2001). Culture and urban mental health. Psychiatric Clinic of North America, 24 (3), 581-93, https://doi.org/10.1016/s0193-953x(05)70249-5

Carr, D. (2019). Methodology, Representation, and Games. Games and Culture, 7-8, 707-723. https://doi.org/10.1177/1555412017728641

Cote, J.E. (2006). Acculturation and identity: The role of Individualization Theory. Human Development, 49 (1), 31-35. https://doi.org/10.1159/000090301

Davis, L.L. (1992). Instrument review: Getting the most from your panel of experts. Applied Nursing Research, 5, 194-197. https://doi.org/10.1016/S0897$1897(05) 80008-4$

Feldman, J. (2001). Bayesian contour integration. Perception \& Psychophysics, 63 (7), 1171-1182. https://doi.org/10.3758/bf03194532

Geethanjali, B., Adalarasu, K., Hemapraba, A., Kumar, S.P., \& Rajasekeran, R. (2017). Emotion analysis using SAM (Self-Assessment Manikin) Scale. Biomedical Research, 28 (Special Issue), 18-24.

Gavrov, S., \& Klyukanov, I. (2015). Modernization, sociological theories of. In Wright, J.D, International Encyclopedia of the Social \& Behavioral Sciences, 2nd edition, Vol 15 (pp.707-713). Oxford: Elsevier.

Hall, C.M., Sharples, L., Cambourne, B., Macionis, N., Mitchell, R., \& Johnson, G. (2004). Wine tourism around the world - development, management and markets. Burlington, MA: Elsevier Butterworth-Heinemann

Hooker, V.M. (2003). A short history of Malaysia: Linking east and west. Crows Nest, N.S.W: Allen \& Unwin

Inglehart, R. (2007). Modernization and post modernization: Cultural, economic, and political change in 43 Societies. In book: Encyclopedia of Sociology (pp.3071-3078). United States: Princeton University Press

Kendall, D (2007). Sociology in our times (6th ed.). Belmont: Thomson/Wadsworth.

Kimchi, R. (2000). The perceptual organization of visual objects: a microgenetic analysis. Vision Research, 40 (10-12), 1333-1347. https://doi.org/10.1016 /S0042-6989(00)00027-4

Klevjer, R. (2019). Virtuality and Depiction in Video Game Representation. Games and Culture, 7-8, 707-723. https://doi.org/10.1177/1555412017727688

Lambert, K.G., Nelson, R.J., Jovanovic, T., \& Cerda, M. (2015). Brains in the city: Neurobiological effects of urbanization. Neuroscience Biobehavioural Review, 58, 107-122. https://doi.org/10.1016/j.neubiorev.2015.04.007

Mattison, S.M., \& Sear, R. (2016). Modernizing evolutionary anthropology: Introduction to the special issue. Human Nature, 27(4), 335-350. https://doi.org/ $10.1007 / \mathrm{s} 12110-016-9270-\mathrm{y}$

McCrae, R.R., \& John, O.P. (1992). An introduction to the Five-Factor Model and its applications. Journal of Personality, 60 (2), 175-215. https://doi.org/10.1111/j.1467-6494.1992.tb00970.x

Othman, I. (2002). Sejarah Malaysia (1800-1963). Kuala Lumpur: Utusan Publications.

Peterson, M.A., \& Kimchi, R. (2013). Perceptual organization in vision. In Reisberg, D., Oxford Handbook of Cognitive Psychology (pp.9-31). New York: Oxford University Press

Posner, J., Russell, J.A., \& Peterson, B.S. (2005). The Circumplex Model of Affect: An integrative approach to affective neuroscience, cognitive development, and psychopathology. Development and Psychopathology, 17, 715-34. https://doi.org/10.1017/S0954579405050340

Pridmore, P., Thomas, L., Havemann, K., Sapag, J., \& Wood, L. (2007). Social capital and healthy urbanization in a globalized world. Journal of Urban Health, 84 (Suppl 1), 130-143. https://doi.org/10.1007/s11524-007-9172-8

Punitha, S., \& Kumaran, S. (2014). Cultural assimilation among Malays and Indians in Malaysia. Journal of Indian Culture and Civilization, 1, 34-45. https://doi.org/10.6007/IJARBSS/v6-i11/2372

Rolls, E.T. (1999). The brain and emotion. New York: Oxford University Press.

Russell, J.A. (1991). Culture and the categorization of emotions. Psychological Bulletin, 110, 426-450. https://doi.org/10.1037/0033-2909.110.3.426

Russell, J.A. (2003). Core affect and the psychological construction of emotion. Psychological Review, 110, 145-72. https://doi.org/10.1037/0033-295x.110.1.145

Sahak, S., Nordin, R., \& Ishak, M.K. (2020). The plight of refugees in Malaysia: Malaysia as a transit country in protecting refugees' rights. Journal of Nusantara Studies, 5(1), 378-394. https://doi.org/10.24200/jonus.vol5iss1pp378-394

Sam, D.L., \& Berry, J.W. (2010). Acculturation: when individuals and groups of different cultural backgrounds meet. Perspectives on Psychological Science, 5(4), 472-481. https://doi.org/10.1177/1745691610373075

Shafie, F., \& Zainudin, R. (2000). Sejarah Malaysia. Kuala Lumpur: Penerbit Fajar Bakti Sdn. Bhd.

Sparkman, D.J., Eidelman, S., Dueweke, A.R., Marin, M.S., \& Dominguez, B. (2019). Open to diversity: Openness to experience predicts beliefs in multiculturalism and colour-blindness through perspective taking. Journal of Individual Differences, 40, 1-12. https://doi.org/10.1027/1614-0001/a000270

Styliadis, C, Ioannides, A.A., Bamidis, P.D., \& Papadelis, C. (2018). Mapping the spatiotemporal evolution of emotional processing: A MEG study across arousal and valence dimensions. Frontiers in Human Neuroscience, 12, 322. https://doi.org/10.3389/fnhum.2018.00322

Turan, T., \& Besiril, A. (2008). Impacts of urbanization process on mental health. Anatolian Journal of Psychiatry, 9, 238-243. https://doi.org/10.1177/ 0022022102250249

Ubaithulla. (2001). Namathu Nadu Nam Makkal: Malaysia 'Our Country Our People: Malaysia'. Kuala Lumpur: Ubaidi Foundation.

Wagemans, J, Elder, J.H., Kubovy, M., Palmer, S.E., Peterson, M.A., \& Singh, M \& von der Heydt, R. (2012). A century of Gestalt psychology in visual perception: I. Perceptual grouping and figure-ground organization. Psychological Bulletin, 138(6), 1172-1217. https://doi.org/10.1037/a0029333

Wolters, O.W. (1999). History, culture, and region in Southeast Asian perspectives. Singapore: Cornell University Southeast Asia Program Publications

Yuan, J., Zhang, J., Zhou, X, Yang, J., Meng, X., Zhang, Q., \& Li, H. (2012). Neural mechanisms underlying the higher levels of subjective well-being in extraverts: Pleasant bias and unpleasant resistance. Cognitive, Affective and Behavioural Neuroscience, 12, 175-192. https://doi.org/10.3758/s13415-011-0064-8

Zainal Abidin, Z.H., Habidin, N.F., Yusof, M.Y., Hassan, P., Yaacob, H.R., Yaacob, M., \& Noh, A.M. (2016). Assimilation of the Malay culture towards the straights of Chinese community in the state of Kelantan: Study in Kampung Pasir Parit, Chetok, Pasir Mas, Kelantan. International Journal of Academic Research in Business and Social Sciences, 6 (11), 38-51. https://doi.org/10.6007/IJARBSS/v6-i11/2372

Zhang, Q., Liu, R., Diggs, L.A., Wang, Y., \& Ling, L. (2019). Does acculturation affect the dietary intakes and body weight status of children of immigrants in the U.S. and other developed countries? A Systematic Review. Ethnicity and Health, 24(1), 73-93. https://doi.org/10.1080/13557858.2017.1315365

*** Department of National Art and Culture, Malaysia (2020, April 15). Retrieved from http://jkkn.gov.my/ms/traditional

*** Department of National Heritage Malaysia (2020, April 25). Perisytiharan warisan kebangsaan 'Declaration of national heritage 2015'. Retrieved from https://www.hrdnet.com.my/department-of-national-heritage.html

*** Department of Statistics Malaysia (2020, April 25). Population projection (Revised), Malaysia 2010-2040. Retrieved from https://www.dosm.gov.my/v1/ index.php?r=column/cthemeByCat\&cat=118\&bul_id=Y3kwU2tSNVFDOWp1YmtZYnhUeVBEdz09\&menu_id=L0pheU43NWJwRWVSZk1WdzQ4TlhUUT09 